\title{
THE EARLY MARRIAGE AMONG THE FARMING COMMUNITY
}

\author{
Arropi Hikmah ${ }^{1}$, Muhamad Fadhil Nurdin ${ }^{2}$ \\ Program Pasca Sarjana Sosiologi, FISIP, Universitas Padjadjaran \\ aroppihikmah@yahoo.com
}

\begin{abstract}
ABSTRAK
Artikel ini berfokus pada pernikahan dini di antara komunitas petani. Pernikahan adalah institusi sosial yang diakui di setiap masyarakat. Pernikahan di usia muda adalah pernikahan yang dilakukan oleh pasangan muda yang berusia di bawah 21 tahun. Pada hakekatnya perkawinan adalah ikatan lahir bathin antara seorang pria dengan seorang wanita sebagai suami isteri dengan tujuan membentuk keluarga (rumah tangga) yang kekal, bahagia dan sejahtera. Pernikahan pada umumnya dilakukan oleh orang dewasa dengan tidak memandang pada profesi, agama, suku bangsa, miskin atau kaya, tinggal di desa atau di kota. Tujuan penelitian ini untuk mengetahui apa faktor penyebab pernikahan dini di kalangan komunitas petani dan mengetahui positif negatif dari pernikahan dini. Metode yang digunakan adalah metode kualitatif menggunakan analisis data model interaktif yang terdiri atas empat komponen, yaitu pengumpulan data, reduksi data, penyajian data dan penarikan kesimpulan. Hasil penelitian menyatakan bahwa faktor penyebab pernikahan dini di kalangan komunitas petani ada 6 faktor yaitu: (1) Pendidikan. (2) Biologis. (3) Hamil Sebelum Nikah. (4) Pemahaman Agama. (5) Ekonomi. (6) Adat Istiadat dan Budaya.

Kata kunci : pernikahan muda, komunitas petani.
\end{abstract}

\begin{abstract}
This article focuses on early marriage among the farming community. Marriage is a social institution that is recognized in every society. Marriage at a young age is a marriage performed by young couples under the age of 21 years. In essence marriage is a physical bond between a man and a woman as a husband and wife with the aim of forming a family (household) that is eternal, happy and prosperous. Marriage is generally done by adults who do not look at the profession, religion, ethnicity, poor or rich, live in the village or in the city. The purpose of this study is to find out what factors cause early marriage among the farming community and know the negative positives of early marriage. The method used is a qualitative method using an interactive model data analysis consisting of four components, namely data collection, data reduction, data presentation and draw conclusions. The results of the study state that the factors that cause early marriage among the farming community are 6 factors: (1) Education. (2) Biology. (3) Pregnancy before Marriage. (4) Understanding of Religion. (5) Economy. (6) Customs and Culture.
\end{abstract}

Keywords: young marriage, farmer community.

2. Program Pasca Sarjana Sosiologi, FISIP, Universitas Padjadjaran
m.fadhil.nurdin@unpad.ac.id 


\section{INTRODUCTION}

In Indonesia the problem of early marriage is a problem that can be said to be serious. Marriage law in this country refers to Law No. 1 of 1974 concerning marriage, where one of the points in the law requires that the marriage age limit is a minimum of 16 years for women. Marriage at a young age is now starting to be warmly discussed, including marriages that took place in the village of Cikancung, Bandung Regency. Marriage seems to be easy to implement, both from people who are able or not able to carry out as long as they have the intention, and dare to be responsible.

Marriage at a young age in the village Cikancung is very much influenced by the traditions inherited from the ancestors as well as their previous matchmaking system since the age of the children is still being carried out. Marriage at a young age is a physical and mental bond between a man and a woman as a husband and wife with the aim of forming a happy and eternal (family) household. Where the prospective husband must be able and ready, both body and soul to get married so that they can realize the purpose of a good marriage without ending in divorce and to get good and healthy offspring. For this reason, the marriage of their prospective husband and wife must not be prepared to hold a marriage bond. Where the prospective husband must be able and ready, both body and soul to get married so that they can realize the purpose of a good marriage without ending in divorce and to get good and healthy offspring. For this reason, the marriage of their prospective husband and wife must not be prepared to hold a marriage bond.

Many early marriages occur from the past until now. Most of the perpetrators of early marriage are village teenagers who have a lack of education. Village teenagers are mostly embarrassed to get married at the age of 20 and above. The presumption of village youth is more likely to marry at a young age because there is an assumption or myth that women aged 20 years and above are not married means "Old Virgin". The fundamental problem of a girl is that when she reaches adulthood, many parents want their children not to become spinsters. Being a spinster for most people is considered a form of deficiency that occurs in women. For this reason, in the shadow of unwarranted fear, many parents marry off their children at a young age. That condition makes the perception that village teenagers will marry first than urban teenagers. These assumptions arise because of the lack of knowledge from the public regarding the importance of education for adolescents.

According to Dadang (2017), many divorce cases are the impact of the young age of couples divorcing when deciding to get married. "Most of those who fail are due to marrying young". 
In the reason for divorce, it's not because of marrying young, but the reason for incompatibility and so on. The problem is of course as one of the effects of marriage carried out without age maturity.

Early marriage will have an impact on the quality of children, family, family harmony and divorce. At that time, adolescent egos were still high. Seen from the aspect of education, the majority of youth in Cikancung Village graduated from junior high school (SMP) and high school (SMA). Most of them did not continue to higher levels, because their socio-cultural factors and the average level of education of their parents were also low, so they did not support children to continue their education to a higher level.

\section{DISCUSS THEORY}

\section{Concepts and Nature Marriage}

Marriage is a binding promise of marriage ceremony that celebrated or carried out by two people with intent legally formalizes matrimony religion, state law and indigenous law. The wedding ceremony has many varieties and variations between nations, tribes and the other one on one race, religion, culture, and social class. The use of indigenous or sometimes specific rules related to certain religious rules or laws anyway (Alfiyah 2010).

Early marriage means a grand institution to bind two people of the opposite sex who was a teenager in the family ties. There are several factors causing early marriage, namely the factor of personal and family factors. From the personal factor teenagers is because they want to avoid sin (sex), and some are due to an "accident". While family factors are because of coercion from parents (Luthfiyati 2008).

Marriage is a contract or agreement between a husband and wife candidates therefore take place through the ijab and qobul or handover. If the marriage ceremony had taken place, then they have promised and are willing to create a harmonious household, will undergo a live and die together in the household (Nasruddin 1976). The meaning of marriage defines as living together of a man and a woman who met certain conditions (Wiryono 1978).

Many definitions of marriage in addition to those already mentioned, include Understanding marriage is a contract between the groom with the bride of the opposite sex (Mufid 2002). Meanwhile, another meaning of marriage is a contract that is lawful sexual relations between men and women (Ramulyo 2004). He concluded that the essence of marriage is a mutually binding agreement between men and women voluntarily to bring happiness in the household. Marriage in Islam is a contract or binding agreement between a man and a woman to justify

72 | SGSIOGLOBAL : Jurnal Pemikiran dan Penelitian Sasiologi, Vol. 3, No. I, Desember 2018 
sexual relations between both parties voluntarily and the willingness of both parties is a happiness of family life which was filled with love and peace (Vegas) ways blessed by Allah SWT. (Wong 2008).Based on the understanding of marriage from several experts in the above it can be concluded that marriage is a covenant (contract) bind held by men and women to form a family commitment, create a harmonious family.

\section{RESEARCH METHODS}

The research method used is a qualitative method. Denzin and Lincoln (2009) explain that qualitative research is the focus of attention in a variety of methods. Qualitative research in its context naturally learns by trying to understand, or interpret, phenomena seen in terms of the meaning attached to humans (researchers). To reveal how social changes occur due to cropping patterns, researchers need active participation, direct and experience-based involvement in the object of research referring to Denzin and Lincoln (2009).

\section{RESEARCH FINDINGS}

\section{Factors Cause Early Marriage}

\section{Education}

The children's educations have a major role. If a child is out of school at the age compulsory school, then spent their time working. Currently the child is already feeling quite independent, so feel able to support themselves. The same thing if the dropouts are unemployed. In the emptiness of time without work to make them end up doing things that are not productive. One of them is in a relationship with the opposite sex, that is if it is beyond the control make pregnancy outside marriage.

\section{Biological}

There are some cases, the filing of marriage because the children have been doing biological relationships like husband and wife. With these conditions, the elderly daughters tend to marry at her, because according to the child's parents of this girl, that because it was not a virgin anymore, and it is becoming a disgrace. Without prejudice to the feelings and confusion of parents, I consider this a solution that possibility at a later date would mislead children. Like a child we've done a great mistake and not fix the error, but the parents would bring the child to a condition that is prone to problems. Because it is so large in the future of child marriage is likely to be conflict.

\section{Pregnant before marriage}

Because of the condition of the girl has been in a state of pregnancy, the parents tend to marry children. There are even some cases, although basically this girl's parents do not agree with the 
prospective in-laws, but because of the condition of her pregnancy, then forced the parents to marry the girl child. There are even cases, even the girls basically do not love her husband, but because already pregnant, it is forced to apply for a dispensation to marry. It all certainly is very dilemma. Good for the girls, their parents and even judges who hear. Due to these conditions, clearly a marriage that will be implemented is no longer as marriage, as mandated by the Act even religion. Because is looming in front of the eyes, flush marriage later this girl later. Marriages performed by a love only possibility at a later biases wobbly, especially if the marriage is based compulsion.

\section{Understanding of Religion}

Because not as doctrine. No part of our society who understand that if the child is in a relationship with the opposite sex, there has been a violation of religion. And as a parent is obligated to protect and prevent it by immediately marrying children. There was one case, where the child's parents claim that if a child in a relationship with the opposite sex is one: "adultery". Therefore, as parents must prevent this by immediately marrying. When a child asked Islamic Courts; lady who had the 16-year-old, the child basically do not mind if we wait until the count the age of 16 years who lived a few months longer. But parents who insisted the wedding should be held. That the child acts mutually same with the boys in "adultery" and as parents are very scared of doom let the child remain in adultery.

\section{Economic}

We still see many cases where parents of debts that could not be paid. And if the old man was in debt to have girls, so the girls will be submitted as a "means of payment" to their accounts. And after the marriage of a child, then "pay off" debts that wrapped around the child's parents. The case came to light recently occurred in the Maros (South Sulawesi). That an old man aged 60 years mrary a-12-year-old child. The child's parents had happy enough, because in addition to debts can be paid as well because these children have been given HP. A story that is very ironic.

\section{Customs and Culture}

In some parts of regions in Indonesia, there are still some understandings of matchmaking. When his daughter had been betrothed since childhood his parents. And will soon be married shortly after the child has experienced a menstrual period. Generally the girls began menstruating at the age of 12 years. It is certain that the child will be married at the age of 12 years, far below the minimum age of marriage mandated by the Act.

The second cause of early marriage, it is occurred not because of the child, the victims are girls. This culture should we wiped out, for the realization of the rights impression between

74 | SGSIOGLOBAL : Jurnal Pemikiran dan Penelitian Sasiologi, Vol. 3, No. I, Desember 2018 
boys and girls. However, this happened in the area of culture, not in an area that is already developed. Adolescent Development and duties in accordance with the growth and development of an individual, from childhood to adulthood, individuals have their respective tasks at each stage of its development. The definition of tasks at each stage of development is that each stage of age, the individual has the objective to reach an understanding (Sumiati 2009).

\section{The Negative Impact Of Early Marriage}

Either biological or physical. Teens, who young married, both physically and biologically not mature enough to have children, so the chances of children with disabilities and children or mothers die during delivery is higher. Marry young also an inherent risk of cervical cancer and pain in the vulva when related intimate.

Psychological. Teenagers who marry before reach an appropriate psychological age typically vulnerable to its adverse effects. At that time the teen is not ready to face the responsibilities that must be carried as an adult. As a result, in the family often quarrel because they can't control his emotions and be traumatized for live is not free. But it would be traumatized again when divorced after a few months of marriage. Yet when such a teenager should be able to enjoy his youth, but when has married a teenager can no longer enjoy her adolescence (Ahmad 2008).

However, if married, both parties must be mature enough and ready to face the problems in the family, be it economic, spouse and children. And it was quite capable of resolving problems in a mature and able to care for their children properly in the future. Actually, if psychological maturity is not determined the age limit because some are already aged but still like a child. Or some are still young but already mature mind. Condition psychological maturity is the main thing because they affect the parenting later in life. Whoever name educates children need maturation itself, so there should be maturity and self-understanding, to be able to understand the child. If it is still childish, then how can a mother protect her son? That there will only be burdened because on one hand they want to enjoy their youth and on the other hand he had to take care of his family. Ideally married it during early adulthood which is about 20 - before 30 years for women, while for men it is 25 years.

The Economy. Usually teens who married early family economy is not good, because due to work less well due to the lack of education. But not everything is as it was, there also can meet their needs because their parents can afford. 
In social. Judging from the social side, early marriage can reduce the harmonization of the family. This is caused by emotions that are still unstable, turbulent young blood and immature thinking.

\section{The Positive Impact Of Early Marriage}

Early marriage also has positive impact namely to avoid fornication (sex). If by getting married at a young age were able to save themselves from "mud puddle", sin and disobedience, then marriage is the best alternative.

\section{Influence Education Against Early Marriage}

A marriage has indirectly fettered the freedom of a person, as in a marriage, there is a responsibility to maintain the integrity of the household. It becomes a significant consideration for deciding to marry. Education is one of the variables used as considerations that obscure the decision to get married, let alone married early.

Implications education by Freud: "Education is to refine and civilize sex impulses to the expectations of the people". Deepen knowledge in the world of education often makes people forget about his personal life. A person does not think about the biological needs were filled due to busy daily life.

Higher education will provide a mature understanding of the individual to choose or decide a case. The people do not want if a bad thing happened to her unintended consequence of decisions taken by him. If the marriage was under 20 years old, then emotionally teenagers still want to adventure to find herself (Suharismi 2006).

Lack of education could be due to economic factors, from economic factors this person is not able to continue his education and also due to the relatively large family. Besides cultural factors also contributed to the lack of education, public education possible in the environment are relatively low cause lazy teenagers continue their education to a higher level.

Marriage ages are younger in rural areas than in urban areas (Dellyana 1988). Early marriages that occurred in the village are usually caused by a low level of education. According to Popenoe (in Ahmadi 1991), the function of education is to (1) the transmission of culture, (2) helping individuals choose and perform social roles, (3) guarantee social integration, (3) as a social innovation. Higher education will provide a mature understanding of the individual to choose or decide a case. The people do not want if a bad thing happened to her unintended consequence of decisions taken by him. 
From previous studies in Indonesia $50-20 \%$ of early marriage performed by a new partner. Early marriage is usually carried out by a young couple whose average age 18, 19 and 20 years old. Nationally, early marriage with the bride is under age 16 as much as $26.9 \%$ (Jalu 2004).

\section{Policies or Measures Taken to Prevent Early Marriage}

To prevent early marriage, the role of parents is very large because of the responsibility for the child in them. Society was supposed to have more attention to the needs of children and not make use of child as a tool for trade and others. Himself teenage should not rush to get married and keep the interaction, because there is still much to be done before marriage is: have less education and a decent job so that they can make a living with his family soon enough.

\section{CONCLUSION}

From what has been discussed, it can be concluded that early marriage is not supposed to do, and if we think that early marriage is very risky in teens, because of early marriage ruin the future, the young generation, and also a lot of bad effects that should be in face up teen who did early marriage. Hence, the thing we should do is to avoid early marriage and thinking far ahead. However, if getting married at a young age able to save themselves from sin and disobedience mud, then marriage is the best alternative. Conversely, if the delay marriage until the ripe old age contains a positive value, then it is more tendensius.

\section{REFERENCES}

Mubasyaroh. 2016. "Analysis of the Factors That Cause Early Marriage and Its Impact on the Actor." Yudisia Journal 7(2).

Dellyana. 1988. Marital Status Interfaith review of legislation.

Ahmadi, Abu. 1991. Classical and Modern Sociology, Sketches Initial Thoughts. Semarang: UPT UNNES PRESS.

Jalu. 2004. Marital Status Interfaith Review of Marital Law 1/1974. Jakarta: PT Dian Rakyat.

Suharsimi. 2006. Research Procedure a Practical Approach. Jakarta: Reinka Reserved.

Luthfiyati, Dian. 2008. Medical Research Methodology. Moulds III. Jakarta: Rineka Reserved.

Ahmad, Lily. 2008. Methodology of Nursing Research. Moulds I. Jakarta: Infomedika.

Sumiati, et al. 2009. Teens Health Life and Counseling. Jakarta: Trans Media Info.

Denzin, Norman K and Lincoln, Yvionna S. 2009. Handbook of Qualitative Research. Happened. Dariyatno, et. al. Yogyakarta: Student Library

Djamilah. 2014. Impact of Indonesian Child Marriage. Journal of Youth Study 3(1). 